\title{
PARENT INFLUENCE ON LOAN PRICING BY CZECH BANKS
}

\author{
Alexis Derviz, Marie Raková*
}

\begin{abstract}
:
We investigate the influence which the financial condition of a multinational bank group may have on the lending rates of its affiliates, using data from the ten biggest banks in the Czech Republic under foreign control. The analysis is based on a theory of bank lending in which the implicit opportunity costs of lending by a foreign bank affiliate are influenced by the scarcity of funds within the multinational conglomerate. The theory predicts that parent banks' influence should be stronger in loan segments with more pronounced information asymmetry. Our empirical model, which explains the interest rate charged by the affiliate by means of affiliate-level controls and a parent influence variable, is tested for three categories of commercial non-financial borrowers (domestically owned firms, foreign-owned firms and the self-employed). Evidence of parent influence is found in a limited number of cases of banks and borrower classes for which the constraint on fund flow within the parent bank group is likely to be tight, particularly when the borrower class is of strategic importance for the affiliate's overall performance.
\end{abstract}

Keywords: multinational bank, interest rate, internal capital market, risk, creditworthiness, funding cost.

JEL Classification: G21, G31, F36, D82

\section{Introduction}

The paper analyses the role which the condition of a parent bank may have on the interest rate setting of its affiliate - a subsidiary or branch - in a foreign country. The host country under consideration in this study is the Czech Republic, whose banking sector is dominated by institutions under foreign control: more than 80 per cent of banking sector assets, deposits and loans are held by banks with a foreign majority shareholder or by foreign bank branches.

* Alexis Derviz, Czech National Bank, Na Prikope 28, CZ-115 03 Praha 1, and Institute of Information Theory and Automation, Pod vodárenskou věži 4, CZ-182 08 Praha 8 (alexis.derviz@cnb.cz); Marie Raková, Czech National Bank, Na Prikope 28, CZ-115 03 Praha 1 (marie.rakova@cnb.cz).

This work was supported by Czech National Bank Research Project No. C5/2007. A part of this research was conducted during the first author's participation in the Visiting Scholar Program of De Nederlandsche Bank (DNB) in September-October 2008. Extended consultations with and valuable advice from Iman van Lelyveld (DNB) and Ralph de Haas (EBRD) are gratefully acknowledged. 
The latest global financial crisis has led to the collapse of several multinational banks (MNBs) and it has negatively affected most of the surviving ones. The repercussions for financial stability have been tangible both in the MNB home countries and, in some cases, in the host countries of their affiliates. Shock propagation worked in one of the two directions. Either the parent's condition deteriorated to the point of inability to maintain the liquidity and/or solvency of its affiliates (e.g. the near-failure and rescue of Fortis Group in the Benelux countries in September 2008), or the affiliate's asset values fell so much that the parent was overburdened with guarantee calls and balance sheet repair needs in them (the case of Scandinavian banks in the Baltic states or Austrian banks in some East European countries in the latest phase of the crisis). Naturally, mechanisms of shock propagation through internationally active banks are now at the center of policymakers' attention.

However, the ability of MNBs to transmit positive and negative credit shocks across borders is not limited to periods of financial turmoil. A part of excess funds within a bank group moves between parent and affiliates on a regular basis. Affiliates in host countries with tight financing constraints (high money market rates, tough competition for deposits, etc.) may take recourse to funds from the parent. A converse situation, of which the Czech banking sector is a good example, is when affiliates with an overhang of free liquidity receive incentives from the parent to divert funds from local lending to preferential alternatives abroad with a higher yield (including lending to the parent itself up to the standing regulatory limit). This has implications for the affiliate's loan pricing and volume, as the total funding costs of foreign bank affiliates will thus be a blend of domestic (above all, domestic deposits and the interbank money market) and foreign factors. It should then be a matter of empirical analysis to determine the significance of the discussed "parental" cost component in the actual lending rate setting of foreign bank affiliates. So, the present paper is not about MNB actions in a crisis, but seeks instead to uncover more general behaviour patterns.

With this motivation in mind, we first look at a theoretical justification of the relationship between a foreign bank affiliate, with access to intra-group funding from its parent bank, and a risky client. The equilibrium lending volume and lending rate shall be influenced by the opportunity cost of the affiliate's funding, which, in turn, depends on the financial condition of the parent bank. This fact guides our choice of empirical priors, as implied by theory.

Our empirical model is applied to foreign bank affiliates in the Czech Republic in the 3.5 year period preceding the final phase of the latest financial crisis (between January 2005 and June 2008). That is, we deliberately concentrate attention to times of "regular" banking sector operation. We collect data on interest rates on new loans in ten commercial banks, all of them under foreign control, at monthly frequency. Besides interest rates and loan volumes, they also contain a rough sectoral classification of borrowers. Of those, we select non-financial legal persons only, and additionally isolate domestically owned firms, foreign-owned firms and self-employed individuals. After constructing several control variables on the affiliate level, we complete the empirical 
model with a "parent bank condition" variable (to be introduced in Subsection 4.1.2) to capture scarcity of funds in the internal capital market of the multinational bank group as a whole. The presence and significance of this parent effect is then tested for volume-weighted averages of interest rates in each of the named borrower categories.

The degree of detail of our affiliate-level information is substantially higher than that of the information on parent banks: essentially, the only reliable monthly data on their operation and condition present in the public domain is that extractable from market prices of their traded liabilities. Therefore, the exercise we undertake is necessarily crude and cannot guarantee the detection of all subtleties of internal capital market workings in a multinational bank group. Nevertheless, it is possible to set up criteria for both the cases in which the parent effect is unlikely to be important and the cases in which it becomes prominent enough even to surface through all the noise present in our data.

Our findings can be summarized as follows. Parent bank effects are absent in banks with slack fund flow constraints to/from the parent. The said constraint is usually not uniformly tight across loans to all categories of borrowers, but instead comes about as a consequence of the strategic importance of a certain segment of clients for the affiliate (and hence for its performance inside the bank group). Banks that concentrate on more opaque borrowers should be more exposed to the parent effect. Finally, there is no uniform effect of the parent home country money market on interest rates charged by the affiliate in the host country. That is, the intra-banking group flow of funds seems to be effectively disconnected from short-term interbank market influences. Apparently, cross-financing between entities in different countries is subject to detailed earmarking and other bank-internal constraints that do not allow for easy interaction with shortterm liquidity management. Symptomatically, the parent's stock price, at least at times when it is mirroring its current and prospective earnings correctly, contains more information on affiliate funding than both the money market rate differences and the bond yield spreads of that bank.

The remainder of this paper is structured as follows. In Section 2, we review the related literature, after which Section 3 discusses the theoretical background. Section 4 then describes the results of our empirical analysis of the parent bank effect. Section 5 concludes.

\section{Literature Review}

Our paper is mainly related to two strands of the financial intermediation literature. The first one is the theory and empirics of banks' lending rates. For most developed countries, there is considerable formal and informal evidence of sizeable crosssectional variation of lending rates across banks (see e.g. Berlin and Mester, 1999, for the U.S.; or Gambacorta, 2008, for Italy). Initially, the most popular explanation of this variance, provided by credit risk theory (Duffie and Singleton, 2003), relied on heterogeneous client creditworthiness. Compared to that, papers dealing with bank-specific determinants of lending rates are less numerous (see e.g. Green, 1998; Kishan and Opiela, 2000; Gambacorta and Mistrulli, 2004). 
Second, our paper is related to the study of bank-internal capital markets' role in lending decisions. Industrial organization theory has dealt with the effects of vertical integration on product pricing - see, for example, Grossman and Hart (1986) or Helfat and Teece (1987). Studies of the vertical integration phenomenon in the financial intermediation literature have looked mostly at its causes and relation with market structure (Berlin and Mester, 1998), but not at its consequences for interest rate setting. Also the literature studying the role of bank refinancing conditions in the monetary policy transmission (Bernanke and Gertler, 1995) has primarily analyzed the volume of bank lending but not the interest rates charged. Froot and Stein (1998) draw a general picture of an internal capital market within a bank holding. This theory was developed in, e.g. Gertner, Scharfstein, and Stein, 1994; Stein, 1997; Scharfstein and Stein, 2000; and Scharfstein, 1998.

Empirical evidence on internal capital markets within banking groups is mainly available for the United States. Houston et al. (1997) show for bank holding companies that the credit growth of a subsidiary is negatively correlated with the loan growth in other U.S. subsidiaries of that holding. Dahl et al. (2002) show that such correlated credit growth patterns are due to net equity financing flows between the parent bank and its various subsidiaries. De Haas and Van Lelyveld (2010) and Derviz and Podpiera $(2007,2011)$ find that lending by subsidiaries of foreign banks is sensitive to home-country economic growth as well as to the financial health of the parent bank and of other subsidiaries in the same banking group. Again, all of these papers focus on the effects of lender characteristics on the amount of credit. This paper differs in that we have an explicit focus on the effect of lender characteristics, in particular foreign ownership, on the pricing of their loans.

\section{Theory of Lending Rate Determination}

Below, we sketch a bank-client model of lending in an oligopolistic banking sector. ${ }^{1}$ Some consequences of the resulting credit market frictions are likely to be important in our context of foreign-controlled bank operation, and point at relevant explanatory variables for loan prices set by a given lender. A detailed formal treatment of the model is given in Derviz and Raková (2009).

Like any other bank ( $c f$. the Stiglitz and Weiss (1981) model in which banks internalize the consequences of interest charged on the firm's ability to repay ${ }^{2}$ ), an affiliate of a multinational bank is faced with a trade-off. It can offer a high lending rate, which

1 The fact that, generically, the bank-client relationship is not fully competitive on either part was recognized by the literature a long time ago (Santomero, 1984) and confirmed by more recent literature linked to the concept of client "catch-up" in a specific bank, see e.g. Bonaccorsi di Patti and Dell'Ariccia (2004) or Dell'Ariccia and Marquez (2004).

2 The omission of a number of formal conditions that would guarantee an internal equilibrium solution was one of the weak points of the original Stiglitz and Weiss (1981) approach, subject to a critique by Arnold and Riley (2009). This may have set limits on its technical - if not conceptual impact on the subsequent theoretical literature on bank lending. 
means high revenue from solvent borrowers, but also a higher probability of default due to moral hazard. It can also set a lower rate, which will reduce the default probability but at the same time reduce interest income on non-defaulting loans. The bank chooses an optimal lending rate that maximizes profit from the loan given its cost of funds, which in turn are a function of parent bank characteristics. In particular, we expect that - in line with the literature on internal capital markets cited in Section 2 - the foreign bank affiliate's funding costs are partly determined by the parent bank's financial strength and alternative investment opportunities.

The bank first announces the lending rate and the borrower then decides the loan volume it demands at this rate (i.e. we model a credit line as the most widespread form of corporate loan in our sample, and also use the aforementioned partial market power of the bank). The borrowed funds are invested in a project that produces revenues in the second period. If the borrower earns less than it owes to the bank in period 2, it will go bankrupt and all revenues will go to the bank. The revenue is uncertain and the knowledge the borrower and the bank have ex ante about its probabilistic properties is asymmetric: the bank does not know either the borrower-specific productivity component or its weight in the compound productivity value (borrower type).

Credit extended by the affiliate needs to be funded and this funding, in a purely domestic bank, would come from capital and the totality of borrowed domestic sources, normally comprising deposits and the domestic money market. In a foreign bank affiliate, the picture becomes more complex. Funds coming from the controlling shareholder (parent bank) are not just capital in either the accounting or regulatory sense. For one thing, if the affiliate is a branch rather than a subsidiary, capital does not exist and one can only talk about the budget allocated to that division by the headquarters. For another, even if the affiliate is a separate legal entity (subsidiary), its relationship with the parent is rarely limited to the provision of mandatory capital (e.g. subsidiaries are often overcapitalized). But, most importantly, parent banks often engage in maintaining a variable debt position w.r.t. the affiliate by either lending to, or borrowing from it, depending on the liquidity available on either side. So, instead of capital which is a small percentage of loan volume, as per the regulatory requirements, the affiliate balance sheet contains a net position vis-à-vis the parent that can be both positive and negative. The exact split of the funding between domestic sources and the internal capital market of the parent bank group depends on their prices.

Clearly, if the affiliate can acquire cheap liquidity from the parent, the effective cost of funds faced by it sinks below the domestic level. On the contrary, even if the domestic cost of funds is low but the parent bank's demand for liquidity makes it offer a high price in the internal capital market of the holding company, funds intended for domestic lending become relatively expensive due to a high opportunity cost.

In the generic case of an internal optimal solution to the affiliate funding decision problem, the unit funding cost is driven by the "outside option" of the MNB internal capital market price, at the same time lying somewhat below it thanks to the existence of domestic financing. This happens regardless of the MNB-internal price being above 
or below the domestic funding cost level. So, in a foreign bank affiliate as opposed to a domestically-controlled bank, one may see a disconnect of the internal funding costs from the monetary conditions in the host country. This disconnect should have implications for loan pricing by foreign bank affiliates, a conjecture that can be cast in an empirically testable form.

Another empirically relevant case is the one in which the optimal balance sheet is not given by an internal solution. This happens if the internal capital market price is either too low or too high. Then a non-negative foreign position vis-à-vis the parent is redundant since domestic financing sources cover the whole loan demand and the parent funding constraint is slack. For instance, taking recourse to parent funds would be too expensive in view of implicit transaction costs attached to it. A priori, such natural autarchy cannot be ruled out, and it is also born out by the data on several banks in our sample (cf. Section 4).

Given the cost of funds, the bank will optimize its expected profit with respect to the lending rate. Due to the possibility of default, the expected profit also depends on the information structure and borrower liability clauses. Therefore, the optimal lending rate will depend on a number of borrower characteristics, such as limits to liability, probabilistic parameters of his ex ante solvency distribution and the degree of opacity from the banker's perspective. These factors influence the main first-order link between funding costs and the optimal lending rate. For example, the model predicts that the lowest dependence on funding costs is to be found in the interest rate paid by a hypothetical completely transparent borrower carrying the full consequences of a possible default, whereas the highest dependence is expected for the rate paid by a completely opaque borrower not liable at default. To get an intuitive explanation, observe that the case of complete borrower transparency (the uncertainty is common for the borrower and the lender) and full liability at default corresponds to a market in which the value of the loan is priced fairly based on all relevant information. Naturally, this information should include the cost of lending for the bank, which is being adequately passed through into the rate paid for the loan. As soon as the situation begins to deviate from the "efficient market" baseline, either toward a privately observed component of technology or reduced liability at default, the fair loan pricing also breaks down. One of the consequences is an overshooting in the funding cost pass-through to the lending rate.

The key empirical implication is that the pass-through of the MNB-internal capital market price into affiliate lending rates is heterogeneous across borrower categories. We expect the funding cost sensitivity of the lending rate to grow with bank-borrower information asymmetry and decline with the borrower's growing downside risk at default. Neither characteristic is easily observable. Nevertheless, one can try to proxy them by more readily available variables such as size and ownership, by assuming that small locally owned firms are more opaque than large foreign-owned ones. The former should also represent a more traditional case of limited liability at default. Accordingly, one expects to find a stronger parent-bank impact with local as opposed to foreign- 
owned companies. The same theory points at circumstances under which the parent effect ceases to be visible: a slack funding constraint in the affiliate. The situation does not have to pertain to all borrower classes, only to those that have a less-than-strategic role in the loan portfolio. In the empirical exercise, we identify a number of such banks and make a connection between the relative importance of their loans in a particular category and the lack of parent influence on their price.

\section{Estimation}

\subsection{Data}

\subsubsection{Czech affiliates}

The time span of the observations is 2005:01 (the beginning of availability of both the considered set of MNB in the Czech market and the loan-level data) through 2008:06. The final date marks the end of the period prior to the acceleration of the global financial crisis. The banks selected for the study are the ten biggest institutions - either banks with foreign controlling shareholders (subsidiaries, seven institutions) or foreign bank branches (three institutions) - operating in the Czech retail commercial banking market. If one leaves out specialized institutions (such as building societies) and special purpose government-run banks, then this group of banks under foreign control essentially comprises all non-negligible participants in the Czech commercial banking market. They currently own more than 85 per cent of all banking assets in the Czech Republic, and their shares in deposits and loans also exceed 80 per cent of the sector aggregates. In one of these ten cases, two banks' data were aggregated to reflect a merger of the corresponding parent banks. The de facto merger took place in 2005 even though the two institutions did not start operating in the Czech Republic under a common name until late in 2007. Another foreign-owned institution took over a smaller locally owned one in the course of 2006 and 2007, which had to be reflected in the construction of the consolidated data.

The paper uses data from the internal Czech National Bank (CNB) database of the volumes of, and interest rates on every newly granted loan by each individual bank to non-financial businesses, at monthly frequency. The current structure of the reports collected by the CNB exists since January 2005. From these raw data, we construct several bank-level aggregate measures to be used in the estimation. The overwhelming majority of loans in the dataset ( 91 per cent) are in Czech koruna (CZK), over 6 per cent in euro, and the rest in other currencies, mostly USD. In this study, we only consider loans in CZK, as the most representative segment. Using these loan-level data, we construct volume-weighted lending rates for three broad categories of borrowers as identified in the CNB database: domestically owned firms, foreign-owned firms and self-employed entrepreneurs. We also construct an aggregate lending rate series by pooling the three named and the remaining legal person borrower categories. Thus, we have four borrower classes altogether: all, domestic firms, foreign firms and the self-employed. 
Not all the banks in our set lent to all three named borrower classes during every month covered by the sample. Therefore, only the aggregate (volume-weighted) lending rate series exist for all ten banks; rates charged to domestically owned and foreign-owned companies exist for all months in the sample for nine banks each (although these two lender sets are not identical) and loans to the self-employed exist for only six banks. This circumstance determines the cross-section size of the four pools considered.

As the dependent variable in all the regressions we used the lending spread, defined as the difference between the said volume-weighted monthly average of rates charged (for the given borrower class, across all maturities) and the average Prague interbank offer rates with 12 month maturity (1Y PRIBOR) for the same month. The spread with respect to the $1 Y$ interbank rate was chosen in accordance with the historically prevailing rate-setting convention: both the prime rate of the bank and the rates negotiated with loan applicants use this quoting rule. Most often, it is applied not just to floating rate loans (which dominate the sample anyway), but to fixed rate contracts as well.

The controls used to co-explain interest rate variation on the affiliate level are the writedown percentage of the loan portfolio value (due to loan defaults or reclassification), the deposit growth rate and the interest margin, all at monthly frequency. The last two indicators were constructed using 12-month moving averages, so that they also contain information on up to 11-month-lagged values by construction. This averaging was conducted not only out of the purely technical need to smooth excessively volatile monthly series, but also because it seemed unlikely that the lending policy-relevant information contained in these two variables would be spread around the bank completely within one month's time. Rather, we expect it to be absorbed gradually by those who decide about new loan pricing. Essentially, the write-down figures are also lagged (by one month) by construction: as a consequence of the formal non-standard loan definition, write-downs reported in a given month refer to losses actually booked one month earlier.

\subsubsection{Parent banks}

Next, we had to choose variables that characterize parent bank factors in affiliate funding costs. Since balance sheet data for most parents are unavailable at the necessary monthly frequency, we had to use market data. Among those, one of the obvious candidates is the home-host interest rate differential, standing for the relative cost of funding in the parent bank domicile in general. Another is the parent bank credit spread obtained from bond yields (or CDS rates). Finally, one ought to look for information contained in other data on parent liabilities, of which the most natural and universally available across the set of banks and time span analyzed is the common stock price. Essentially, there are no other publicly accessible quantitative data at monthly frequency than equity price ones that would get closer to proxying the scarcity of funds in the internal capital market of a banking group. So, one has to use them no matter how many distortions they might contain. 
To be precise, the explanatory variable we use is the parent bank stock performance relative to the equity index for the sector of financials. ${ }^{3}$ This is applied in inverse form: the financials stock index is divided by the stock index of the bank (both normalized to unity on the first month of the sample), so that values above one mean underperformance and those below one mean over-performance compared to the peers in the sector. This choice is meant to capture the relative ease of access by the banking group to interbank market funds in the home country, while eliminating from consideration equity market movements common to all institutions in the sector.

Descriptive statistics of the discussed lending rates can be found in Table 1 of Derviz and Raková (2009), together with the standard normality tests. It turns out that, even in the short sample we are restricted to, the deviations from normality are quite mild.

The equity performance index described above proved to be the only feasible explanatory variable for the lending spread on the parent bank side. Specifically, according to our findings, the credit spreads for individual banks do not systematically differ from the sector-wide aggregates for the same spread against government bond benchmarks. Apparently, traders in the bonds of most big and medium-sized banks do not have access to bank-specific information that would make their prices of different institutions' issues differ by anything but random noise. In other words, this market (not unlike the forex) appears to be a severe case of herding behaviour. So, with the beginning of the subprime mortgage troubles in summer 2007, all credit spreads in the financials segment embarked upon an upward path collectively, making statistical separation of individual institutions from the sector credit spread index problematic. Accordingly, we had to give up on using credit spreads as a reliable bank-specific variable.

As regards the home-host interbank market rate differential, this variable appears to be universally insignificant for affiliate lending spreads (even in cases where the parent effect captured by the equity index is significant - see below). Therefore, although it was included in the original specification, we later removed the interest rate differential from the regressor list, so that quantitative results on this variable are not reported in the sequel. We discuss possible reasons for this outcome at the end of the next subsection.

\subsection{Hypotheses and estimation approach}

As was mentioned in Section 3, the parent bank's influence on loan pricing in the affiliate is likely to gain visibility only when other stronger influences are absent. Indeed, the price of funds set in the internal capital market of the bank group influences the cost of funds in the affiliate only when the constraint on domestic funds is binding and their price is sufficiently high. As one may reasonably conjecture, for many Czech banks - or at least for a number of their important lines of business - this constraint was pretty far from binding in the period covered by our sample. This should hold for banks with a sufficiently wide deposit base in the absence of major expansions into new market segments, mergers or restructuring events.

3 Stock price data are from DataStream. 
In order to recognize an unconstrained affiliate in the above sense, we have used the following measure. Along with the volume-weighted lending rate, we take a similarly defined volume-weighted deposit rate and calculate the resulting loan-deposit spread time series (same monthly frequency, deposit rate values lagged by one period). A bank for which this loan-deposit spread is sufficiently close to white noise (plus a constant) can be viewed as an enterprise with no particular need for additional funding. Objectively, it operates with a stable average profit target derived from the latest recorded costs of funds in deposit form (which, in those cases, is the only form relevant to the affiliate). ${ }^{4}$ We established that a number of affiliates in our sample pass this criterion. For them, one should not expect the parent effect to be prominent in the lending spread decomposition.

Table 1

\section{Parent Effect and Loan-Deposit Rate Spread}

\begin{tabular}{|l|c|c|c|c|c|c|c|c|}
\hline \multirow{2}{*}{ Bank } & \multicolumn{5}{|c|}{ Significance of parent equity performance } & \multicolumn{2}{c|}{$\begin{array}{c}\text { Slope of the } \\
\text { loan-deposit } \\
\text { interest rate } \\
\text { spread }\end{array}$} \\
\cline { 2 - 9 } & Pooled regressions & \multicolumn{3}{|c|}{ Bank-level regressions } \\
\cline { 2 - 9 } & DF & FF & SE & Aggregate & DF & FF & SE & 0.026 \\
\hline $\mathbf{1}$ & + & & & & + & + & & -0.0007 \\
\hline $\mathbf{2}$ & & & & & & & & -0.0068 \\
\hline $\mathbf{4}$ & & + & & & & + & & -0.007 \\
\hline $\mathbf{5}$ & & & & & & & & 0.0004 \\
\hline $\mathbf{6}$ & + & & & & + & & & 0.024 \\
\hline $\mathbf{7}$ & & & & & & & & 0.008 \\
\hline $\mathbf{8}$ & & & & & & & & 0.015 \\
\hline $\mathbf{9}$ & & & & & & + & + & -0.023 \\
\hline $\mathbf{1 0}$ & & & & + & & & & 0.028 \\
\hline
\end{tabular}

Notes: DF - domestic firms, FF - foreign firms, SE - self-employed

+ means significance at least at $10 \%$ level

loan-deposit spread slope values in italics lie below the separation point of 0.02 in absolute value

In view of the short temporal dimension of our sample, we quantified the said loan-deposit rate spread criterion simply by means of the estimated coefficient in the regression of this spread on the calendar time variable, i.e. the loan-deposit spread curve slope value. Unconstrained banks should be those whose absolute slope value is sufficiently close to zero. Exact numbers are given in the last column of Table 1. As one can observe, there is a clear separation of absolute slope values above and below, say, the 0.02 level (the actual separating interval has a width of 0.008 ). So, the banks

4 Note that, as mentioned earlier, in this interpretation, although loan officers quote lending rates to loan applicants as spreads w.r.t. the money market rate (1Y PRIBOR), what they are actually guided by is the spread w.r.t. the average deposit rate. This must be true for unconstrained banks since they neither have to borrow in the interbank market nor tap the internal capital market of the parent bank group. 
with low time trends in the loan-deposit spread (shown in italics in Table 1) are the ones for which no parent effect should be expected. This criterion works for all but one bank. ${ }^{5}$

When the lending rate cannot be satisfactorily explained as a constant mark-up over the past deposit rate, we invoke affiliate-level controls and external influences, including our proxy for the cost of funds on the bank group level. To have a better chance of capturing the parent bank influence correctly, one would first need a powerful enough set of local explanatory variables of the lending spread. Here, the choice, in spite of the abundance of data in the supervisory database, is relatively limited, since there are many strong correlations between indicators taken from balance sheets. We selected the three mentioned in the previous subsection (interest margin, loan value write-down ratio and deposit growth) since they represent the three main influences on the lending rate setting to be expected within a bank (as illustrated by the theory of Section 3): prospective borrower performance hence earnings and debt service potential, default risk, and increase/decrease in available internal funds.

As has become clear from the estimation results, none of the three bank-level controls works equally well for all affiliates. In particular, the explanatory power of the interest margin and write-downs varies considerably between banks, and deposit growth is not of any importance except in a couple of cases. We do not pursue this quest for a satisfactory "bank-internal" statistical model of the lending spread any further, since the relevant internal decision process inside a bank, let alone the operation of the internal capital market within a multinational bank, is unobservable and no set of officially reported indicators, be it the observed market price data or the "semi-observable", i.e. supervisory, data, will be ever able to quantify it in accordance with any theoretical model. Attempts at a more accurate model would go against the practically attainable degree of external visibility of the bank decision process. For our purposes, it is sufficient that the three selected affiliate-level variables in conjunction with a parent variable show some degree of explanatory power and point in the right direction.

To conduct our empirical analysis, we form four pooled objects: one for each of the borrower classes and one aggregate one. We aimed at working with stationary variables, and accordingly, the spread-type series, growth rates and financial ratios that we use are typically stationary (unless measured within short time windows of transitory developments in the market). In conformity with this objective, the dependent variable (lending spread) as well as the four mentioned explanatory variables (the three affiliatelevel ones and the relative parent equity index) are stationary at the pool level along the temporal dimension: both the Levin-Lin-Chu test (the common unit root hypothesis) and the Im-Pesaran-Shin test (the individual unit roots hypothesis) strongly reject

5 And even for that particular bank, the slope is significantly different from zero if one takes the lending rate in the foreign firms category for which the parent effect shows up. Although one would expect the aggregate lending rate value to be primarily relevant (the same loan officer usually deals with applicants from more than one borrower class), it could be a wrong assumption if the bank is extensively diversified and division specializations within it are defined narrowly. 
non-stationarity for all four pools. As regards the same variables for individual banks (which we also used in parallel in independent regressions of bank-level lending spread models with insignificant regressors removed - see Subsection 4.3), their stationary behaviour was also verified, with the probabilities of incorrect unit root rejection by the standard ADF test never exceeding one per cent.

For each of the pools, we regress the affiliate lending spread on the three affiliate control variables discussed and the parent influence variable with the help of a bank fixed effect specification. Formally, the estimated equation for borrower class $b$ ( $b=$ domestic firms, foreign firms, the self-employed, all non-financial borrowers) is

$$
l s_{i t}^{b}=c_{i}^{b}+a i_{i}^{b} \text { Intmar }_{i t}+a w_{i}^{b} \text { writedown }_{i t}+a d_{i}^{b} \text { depgr }_{i t}+\text { ap }_{i t} \text { pareq }_{i t}+\varepsilon_{i t}^{b} .
$$

Here, $i$ is the bank index, $t$ is the period (month in the range 2005:01-2008:06), $c_{i}^{b}$ is the bank fixed effect and $\varepsilon$ is the error term. $l s$ (the dependent variable) is the lending spread in class $b$, Intmar is the interest margin (12M moving average), writedown is the percentage of write-downs of the current value of loans, depgr is the deposit growth rate (the ratio of two subsequent $12 \mathrm{M}$ moving averages of deposit levels less one) and pareq is the inverse of the parent equity index relative to the financials index - the parent effect we are looking for.

The originally included $1 Y$ EURIBOR-PRIBOR ${ }^{6}$ differential was dropped from all the regressions as uniformly insignificant. One can conjecture that this insignificance has to do with the specifics of the internal capital market mechanism. Apparently, parent banks do not either systematically raise funds in the home country money market to be channeled into affiliates (funds they do channel come from other sources) or use funds borrowed from affiliates to lend in the interbank market at home. That is, shifting funds between country units is subject to constraints and detailed earmarking which one cannot detect in the official data releases. Otherwise, the chosen specification produces some useful insights that we comment on next.

\subsection{Results}

The results of our pooled regression exercises show that the parent bank influence is not present in every affiliate. On the other hand, with the exception of one borrower class and one bank, wherever the parent impact is significant, it has the right sign, i.e. a potential increase in the costs of funds for the parent bank (and the whole banking group) leads to an increase in affiliate lending spreads ceteris paribus. Complete estimation results of the four pooled fixed effect regressions can be found in the four panels of Table 2 in Derviz and Raková (2009).

The parent effect tends to be statistically insignificant for affiliates satiated with host country depositor funds. Moreover, the parent bank effect can materialize in loans to one borrower class and be absent in others, suggesting that credit funding policy

6 This differential was tried both with and without exchange rate adjustment. 
toward different categories of clients in an affiliate can be more or less autonomous from the bank group-wide directives. So, lending to the self-employed, as the riskiest segment of all, seems to be typically funded from local sources. Lending spreads charged to the self-employed do not show any significant parent influence, except for one bank in which this category of borrowers occupies a more prominent position than elsewhere in the sample.

The greatest bank-by-bank dispersion of the results on parent influence shows up in credit to foreign-owned firms. This is probably a consequence of different weights of loans to non-residents for different affiliates. That is, the less important foreign firms are, the less their pricing is dependent on the parent situation.

Altogether, in banks for which the effect is traceable in the first place, loan pricing to domestically owned firms shows the highest degree of parent influence. This is perhaps due to the fact that this segment is dominant in the loan portfolio and thus plays a strategic role for the affiliate's overall performance. Hence it is more likely to be closely observed by the parent's management. Due to the prominence of domestic firms in the client base, one sees significance of the parent bank's situation for the aggregate lending spread (all borrower classes) for most banks in which the effect is significant in the domestic firm category.

Table 2

Individual Bank Regressions

\begin{tabular}{|c|c|c|c|c|c|c|c|c|c|c|c|c|}
\hline \multirow[b]{3}{*}{ Bank } & \multicolumn{12}{|c|}{ Borrower class } \\
\hline & \multicolumn{4}{|c|}{ Domestic firms } & \multicolumn{4}{|c|}{ Foreign firms } & \multicolumn{4}{|c|}{ Self-employed } \\
\hline & im & wd & dg & peq & im & wd & dg & peq & im & wd & dg & peq \\
\hline 1 & & * & * & * & & * & * & * & & & & \\
\hline 2 & * & & * & + & * & & & & & * & * & \\
\hline 3 & & * & & & & & & & & & & \\
\hline 4 & - & * & - & + & - & * & & * & & * & & \\
\hline 5 & & * & * & & & * & & & & * & - & \\
\hline 6 & * & & & * & & * & & & & & & \\
\hline 7 & * & & & & * & & & & & & & \\
\hline 8 & * & & & & & - & & & * & & - & \\
\hline 9 & * & & * & - & & * & * & * & & * & * & * \\
\hline
\end{tabular}

Notes: im - interest margin, $w d$ - write-down ratio, $d g$ - deposit growth rate, peq-parent equity relative to sector index

* means significance at least at $10 \%$ level in full and reduced specifications, + is significance at least at $10 \%$ level in at least one specification, - means significance with wrong sign 
As could be expected, the poorest results (in terms of both estimation diagnostics and the overall significance of the explanatory variables, including the parent influence) come up in cases in which the bank group underwent structural changes affecting its stock value. The most prominent such case was a takeover of the parent by another bank and subsequent delisting on the home stock exchange. The remaining small quantity of stock traded in other exchanges, although its price was growing above that of its peers, had, for reasons such as low liquidity and reduced transparency, very little to say about the internal fund cost in the newly emerging holding.

For each of the selected borrower classes, estimation delivers two groups of banks. For one, we obtain an entirely insignificant parent influence. As was conjectured, those must be affiliates with unconstrained funding. For the remaining banks, the parent influence on lending spread is clearly significant. The outcome survives when one goes over from individual bank regressions (Table 2) to a pooled regression (or back). In other words, cross-sectional interactions are not the principal driving force of the results. On the other hand, abandoning the pool in favour of individual bank models has the advantage of allowing us to remove insignificant affiliate-level variables from the individual affiliate regressions. Some results concerning the significance of parent situation become sharper when one excludes insignificant controls. These excluded variables are different for different banks, suggesting that bank-internal mechanisms of fund allocation and loan pricing can be quite diverse. Nevertheless, for most banks, we were able to find factors with a fair explanatory power over the loan pricing. A summary of the significance of the individual variables in the collection of bank-bybank regressions, for each of the borrower classes considered, is given in Table 2.

\section{Conclusion}

We have investigated the possible dependence of bank lending rates in the Czech Republic on credit demand (borrower-related) and credit supply (lender-related) factors, most importantly the funding costs. In an affiliate of a multinational bank group, the latter is, at least potentially, co-driven by the parent bank's condition.

To assess the relative role of the parent effect in loan pricing, we have conducted a bank-level panel regression exercise in which the dependent variable is a volumeweighted lending spread with respect to the Czech interbank market, in a particular category of borrowers. Dependent variables are three bank-level controls (interest margin, classified loan value write-down ratio and deposit growth rate) and the parent group stock performance relative to the peer group of financial institutions. This exercise produced banks both with and without a tangible parent bank effect in each borrower class. The class with the most occurrences of a parent effect was domestically owned firms, followed by foreign-owned firms.

The parent impact, when present, always competes with significant local explanatory factors of the affiliate lending rate. Therefore, parent influence is unlikely to act as the "headline news" or the driving force behind publicly conspicuous changes in the price 
of credit, at least in the absence of major global financial distress. Rather, it assumes the role of a "recessive gene" that can only become important when all other usual drivers of lending spreads fail to exercise their influence.

The results help us understand how far a large-scale presence of foreign bank affiliates is able to influence effectiveness of local monetary policy. It seems that parent bank influence does not have to be a dominating factor in interest-rate setting on aggregate, but can influence the cost of credit in those borrower categories that are of major importance for the affiliate as clients. Accordingly, whereas the host country monetary policy is targeted at credit conditions for everyone, foreign-controlled banks are able to interfere with this policy in a particular class of economic agents that are strategically significant for its business. Altogether, the said parent influence, although occasionally statistically significant, appears to be of subordinate importance economically, at least in the Czech banking sector in the pre-2008 crisis period.

Czech banks in our study were not themselves the sources of financial turmoil. Also, owing to their prevailing deposit-over-loan overhang and adherence to the traditional commercial bank business model at the same time as increasing leverage became "fashionable" around the world, some of them got into the position of net creditors to their parents. Thus, the evidence from the Czech banking sector is not immediately suitable for analyzing extreme crisis-related events in the banks directly involved. Rather, the Czech experience is useful for assessing the impact of evolving parent bank standing, on latent poorly observable components of lending rates (and volumes) in the absence of extreme events. Only then, by extrapolating the assembled experience to "extraordinary" periods, might one be able to make inferences about the impact of shocks originating in the epicenter of the financial turmoil on credit markets lying on its periphery.

\section{References}

Arnold, L., Riley, J. (2009), "On the Possibility of Credit Rationing and Redlining in the Stiglitz-Weiss Model." American Economic Review, Vol. 99, No. 5, pp. 2012-2021.

Berlin, M., Mester, L. (1998), "Intermediation and Vertical Integration." Journal of Money, Credit and Banking, Vol. 30, No. 3, pp. 500-519.

Berlin, M., Mester, L. (1999), "Deposits and Relationship Lending." Review of Financial Studies, Vol. 12, No. 3, pp. 579-607.

Bernanke, B. S., Gertler, M. (1995), "Inside the Black Box: The Credit Channel of Monetary Policy Transmission." Journal of Economic Perspectives, Vol. 9, No. 4, pp. 27-48.

Bonaccorsi di Patti, E., Dell'Ariccia, G. (2004), "Bank Competition and Firm Creation." Journal of Money, Credit and Banking, Vol. 36, No. 2, pp. 225-251.

Dahl, D., Shrieves, R. E., Spivey, M. F. (2002), "Financing Loan Growth at Banks." Journal of Financial Services Research, Vol. 22, pp. 189-202.

Dell'Ariccia, G., Marquez, R. (2004), "Information and Bank Credit Allocation." Journal of Financial Economics, Vol. 72, pp. 185-214. 
De Haas, R. T. A., van Lelyveld, I. P. P. (2010), "Internal Capital Markets and Lending by Multinational Bank Subsidiaries." Journal of Financial Intermediation, Vol. 19, No. 1, pp. 1-25.

Derviz, A., Podpiera, J. (2007), "Cross-Border Lending Contagion in Multinational Banks." European Central Bank WP No. 807.

Derviz, A., Podpiera, J. (2011), "Cross-Border Lending Contagion in Multinational Banks," in Kolb, R. W., ed., Financial Contagion: The Viral Threat to the Wealth of Nations. Wiley, pp. 327-334.

Derviz, A., Raková, M. (2009), "Funding Costs and Loan Pricing by Multinational Bank Affiliates." Czech National Bank WP No. 9/2009.

Duffie, D., Singleton, K. (2003), Credit Risk. Princeton Series in Finance, Princeton University Press.

Froot, K., Stein, J. C. (1998), "Risk Management, Capital Budgeting, and Capital Structure Policy for Financial Institutions: An Integrated Approach.” Journal of Financial Economics, Vol. 47, pp. 55-82.

Gambacorta, L. (2008), "How Do Banks Set Interest Rates?" European Economic Review, Vol. 52, pp. 792-819.

Gambacorta, L., Mistrulli, P. (2004), “Does Bank Capital Affect Lending Behaviour?” Journal of Financial Intermediation, Vol. 13, No. 4, pp. 436-457.

Gertner, R. H., Scharfstein, D. S., Stein, J. C. (1994), "Internal versus External Capital Markets." Quarterly Journal of Economics, Vol. 109, pp. 1211-1230.

Green, C. J. (1998), "Banks as Interest Rate Managers." Journal of Financial Services Research, Vol. 14, No. 3, pp. 189-208.

Grossman, S., Hart, O. (1986), "The Costs and Benefits of Ownership: A Theory of Vertical and Lateral Integration." Journal of Political Economy, Vol. 94, pp. 691-719.

Helfat, C. E., Teece, D. J. (1987), "Vertical Integration and Risk Reduction." Journal of Law, Economics and Organization, Vol. 3, No. 1, pp. 47-67.

Houston, J., James, C., Marcus, D. (1997), "Capital Market Frictions and the Role of Internal Capital Markets in Banking." Journal of Financial Economics, Vol. 46, pp. 135-164.

Kishan, R., Opiela, T. (2000), "Bank Size, Bank Capital and the Bank Lending Channel." Journal of Money, Credit and Banking, Vol. 5, No. 2, pp. 121-141.

Santomero, A. (1984), "Modeling the Banking Firm: A Survey." Journal of Money, Credit and Banking, Vol. 16, No. 4, pp. 576-602.

Scharfstein, D. S., Stein, J. C. (2000), "The Dark Side of Internal Capital Markets: Divisional RentSeeking and Inefficient Investment." Journal of Finance, Vol. 55, pp. 2537-2564.

Scharfstein, D. S. (1998), "The Dark Side of Internal Capital Markets II: Evidence from Diversified Conglomerates." NBER Working Paper No. 6352.

Stein, J. C. (1997), "Internal Capital Markets and the Competition for Corporate Resources." Journal of Finance, Vol. 52, pp. 111-133.

Stiglitz, J., Weiss, A. (1981), "Credit Rationing with Imperfect Information." American Economic Review, Vol. 71, No. 3, pp. 393-410. 